\title{
EHMTI-0191. A novel approach for the treatment of cluster headache - onabotulinumtoxina block of the sphenopalatine ganglion
}

\author{
D Bratbak*, S Nordgård, L Stovner, M Linde, E Tronvik
}

From 4th European Headache and Migraine Trust International Congress: EHMTIC 2014

Copenhagen, Denmark. 18-21 September 2014

\section{Background}

Blockade of the sphenopalatine ganglion with OnabotulinumtoxinA injections (SphenoBlock) represents a novel approach for treating intractable chronic cluster headache (iCCH).

Aim

The aim of this pilot study was to explore the safety aspects and therapeutic potential of SphenoBlock.

\section{Method}

After signing written confirmed consent ten patients with iCCH were injected with $25 \mathrm{U}(\mathrm{n}=5)$ or $50 \mathrm{U}$ $(n=5)$ onabotulinumtoxinA towards the sphenopalatine ganglion in an observational study, approved by the Institutional Review Board, with 6 months follow-up. The procedure was performed with a novel imageguided technique. The primary endpoint was to evaluate safety of the procedure, but change in attack

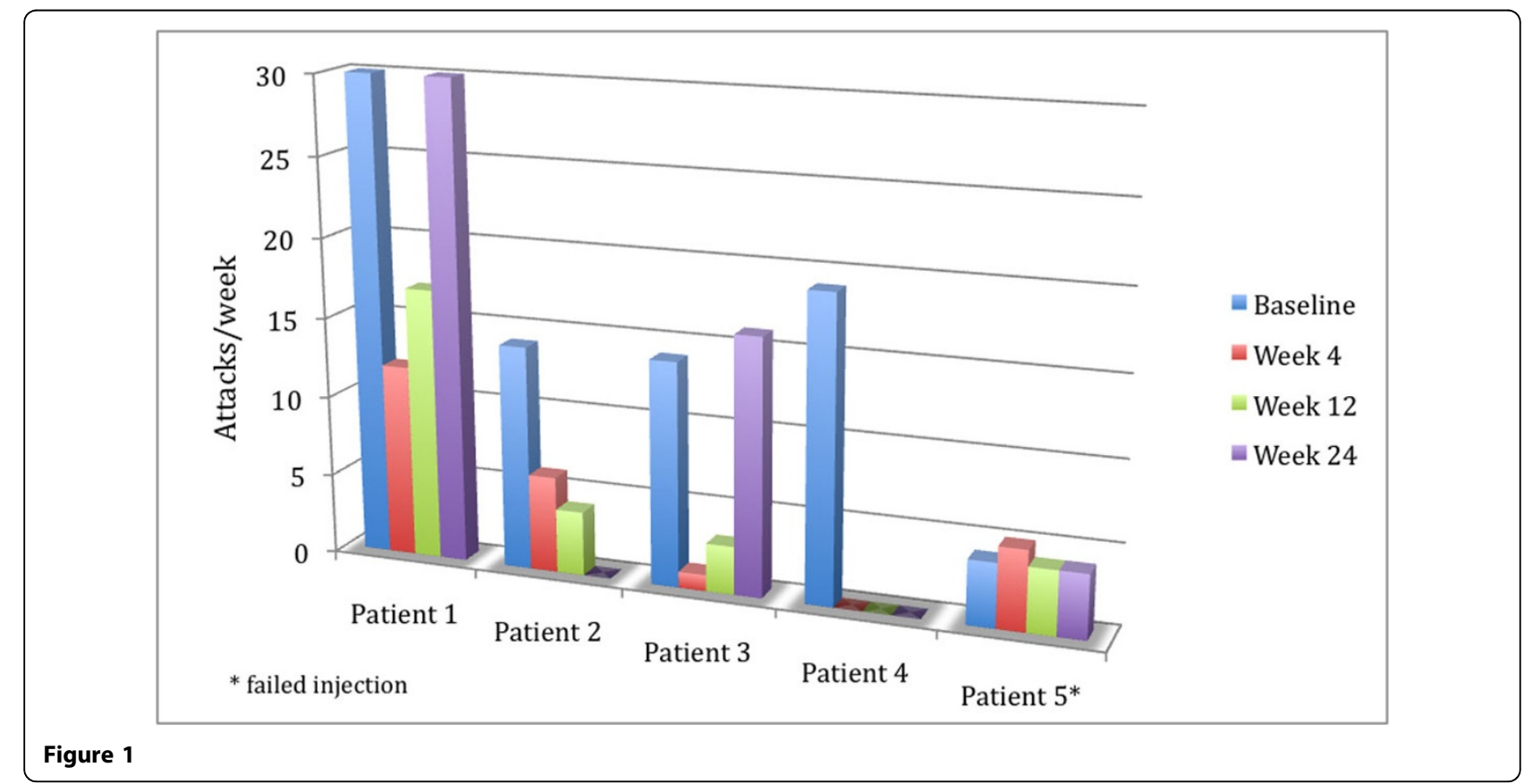

Department of Neuroscience, Norwegian University of Science and

Technology, Trondheim, Norway

C 2014 Bratbak et al; licensee Springer. This is an Open Access article distributed under the terms of the Creative Commons Attribution License (http://creativecommons.org/licenses/by/2.0), which permits unrestricted use, distribution, and reproduction in any medium, provided the original work is properly cited. 
frequency from baseline to week 4, 12 and 24 was also registered.

\section{Results}

Data for the first 5 patients are presented. One patient experienced intermittent ipsilateral visual deficits lasting 4 weeks. Patient number 5 was a failed injection. Four patients were defined as frequency responders $(>50 \%$ reduction from baseline) in week 4,3 patients responded in week 12, and 2 patients in week 24 (Figure 1). Complete study data will be presented at the meeting.

\section{Conclusion}

SphenoBlock in iCCH shows promising preliminary results and give reasons for cautious optimism for further studies on this low-cost alternative treatment of $\mathrm{iCCH}$.

Published: 18 September 2014

doi:10.1186/1129-2377-15-S1-E4

Cite this article as: Bratbak et al.: EHMTI-0191. A novel approach for the treatment of cluster headache - onabotulinumtoxina block of the

sphenopalatine ganglion. The Journal of Headache and Pain 2014

15(Suppl 1):E4

\section{Submit your manuscript to a SpringerOpen ${ }^{\circ}$ journal and benefit from:}

- Convenient online submission

- Rigorous peer review

- Immediate publication on acceptance

- Open access: articles freely available online

- High visibility within the field

- Retaining the copyright to your article

Submit your next manuscript at $\gg$ springeropen.com 